\title{
Master Gardener Perception of Genetically Modified Ornamental Plants Provides Strategies for Promoting Research Products Through Outreach and Marketing
}

\author{
William Klingeman ${ }^{1}$ and Beth Babbit \\ Plant Sciences Department, University of Tennessee, 2431 Joe Johnson \\ Drive, 252 Ellington PSB, Knoxville, TN 37996-4561
}

\author{
Charles Hall \\ Department of Agricultural Economics, University of Tennessee, 2431 Joe \\ Johnson Drive, 252 Ellington PSB, Knoxville, TN 37996-4561
}

Additional index words. agribusiness, education, genetic engineering, green industry, perception

\begin{abstract}
Although genetically modified (GM) ornamental cut flowers are now available commercially, we have no knowledge of consumer perception about GM ornamental plants for landscape use and must make inferences from models drawn for GM foods. If we misjudge the customer, and consumers object to GM ornamental plant products for moral reasons, governmental or scientific mistrust, or limited understanding about GM technology, the market for GM ornamental plant commodities will fail. A survey of Master Gardener volunteers was conducted in 2004 to address this gap. Although Master Gardener perceptions likely differ from those of general U.S. consumers, responses are expected provide insight about beliefs applicable to the gardening public. Results from 607 Tennessee respondents revealed that concerns about GM ornamental plants parallel those expressed in the United States about GM foods. On average, Master Gardeners anticipate slight benefits to both the environment and human health should GM ornamental plants be introduced into the landscape. Male respondents chose perennials to provide the most environmental benefits, whereas females indicated grasses and turf. Genetically modified ornamental plants are also expected to be about the same or less invasive in the landscape than non-GM plants. Of respondents who anticipated more potential for GM ornamental plant invasiveness, women were more likely than men to predict plant escape. Men and women differed in relative acceptance of genes added from different organisms as a method of achieving genetic transformations in plants. This result suggests that outreach and marketing to promote new GM plant products should emphasize attributes of benefit rather than processes used to accomplish the goal. Regardless, although $\approx \mathbf{7 3 \%}$ of $\mathrm{TN}$ Master Gardener respondents reported interest in buying GM ornamental plants if sold commercially, participants advocated a requirement that GM plant products be clearly labeled at point-of-sale.
\end{abstract}

Genetically modified (GM) ornamental plants promise economic advantages if they demonstrate superior ornamental characteristics and plant performance. However, global dialogue about genetic engineering and acceptable plant biotechnology has largely focused on GM foods. By any measure, public perception and concern about the application of biotechnology to achieve aesthetic ends, like ornamental plant manipulations, have been overlooked. Indeed, compared with GM foods, proponents of biotechnology appear to anticipate little public opposition to genetically modified orna-

\footnotetext{
Received for publication 22 Mar. 2006. Accepted for publication 28 May 2006.

${ }^{1}$ To whom reprint requests should be addressed;
} e-mailwklingem@utk.edu. mental plants. Certainly in the United States and Canada, acceptance of GM foods is greater than in Europe and Asia (Cantley et al., 1999; Gaskell et al., 2004; Lapan and Moschini, 2004). Yet nearly all GM products have raised ethical and moral issues among public and environmental interest groups (Gaskell et al., 1999; Lapan and Moschini, 2004; US-FDA, 2000).

We expect these issues to be no less relevant for GM ornamental plants. In fact, in 2001, the American Society of Landscape Architects (ASLA) issued a press release calling for a moratorium on experimental field trials of all GM crops until the USDA review process was reformed and an appropriate review panel is assembled. In the statement, ASLA introduced concerns about GM technology and challenged the sufficiency of the USDA review process to assess public and environmental risks (Argust, 2001).

Still, GM ornamental plants like the 'Moon' Series carnations from Florigene Inc. are already commercially available as cut flowers and several other commercial ventures are underway (Avise, 2004; CHIRO, 2005). To date, introductions of GM cut flowers have garnered little outward attention of advocates from either side of the debate. Yet, our lack of even fundamental knowledge about consumer perception and acceptance of GM ornamental plants relegates our product development, outreach, and marketing energy to assumptions loosely based on parallel inferences drawn from the body of research exploring public perception about safety, risk, and acceptance of GM foods. It is critical that we understand public perception about genetic alterations of ornamental plants or we risk that newly developed GM ornamental commodities will not be accepted into this competitive market sector.

To address this knowledge gap, we undertook a survey of Master Gardener program participants across Tennessee to establish quantifiable benchmarks of perception and expectation about GM technology, as applied to ornamental plants, and identify thematic issues expressed by Master Gardeners about hope and concern for GM ornamental plants to qualify their beliefs. Master Gardener volunteers dependably provide a higher response rate than general public mailings and are a reliable source of broad-ranging landscape and gardening interests and experience. Master Gardener participants are expected to convey their knowledge and enthusiasm, through outreach to the general public, on completing their certification program (Rohs et al., 2002; Ruppert et al., 1997).

\section{Materials and Methods}

In March 2003, a survey instrument was developed to assess Master Gardener general perceptions about biotechnology and marketing implications specific to genetically modified ornamental plants. The validity and reliability of the preliminary questionnaire was examined by a pretest distribution to 130 Memphis-area Master Gardener volunteers in Shelby County, Tenn. Responses from the pretest survey were reviewed and the fourpage survey instrument was revised for clarity.

In April, 1800 questionnaires were mailed with self-addressed, stamped return envelopes (SASE) to participating Tennessee County Extension Agents who coordinated active Master Gardener volunteer programs in 37 of the 95 counties in Tennessee. Individual agents received a packet of either 50 or 100 surveys, depending on the size of their regional membership, and a brief, introductory letter explained our interest in Master Gardener's opinions and encouraged their participation, regardless of any familiarity with the topic. Master Gardeners were provided the opportunity to record $1 \mathrm{~h}$ of educational credit toward sustaining Master 
Gardener Certification as an incentive to complete and return the survey. Questionnaires were to be distributed at the next Master Gardener volunteer meeting. On 22 Sept. and 13 Oct., the State Master Gardener Coordinator sent e-mail reminders to County Extension Agents encouraging their program participants to return completed surveys using the provided SASE.

Statements designed to assess individual position on acceptance of risk and willingness either to try new things or new ways of doing things were included and scored $-2=$ "strongly disagree" to 2 = "strongly agree" with 0 as neutral. Self-reported scales were provided to assess biotechnology-related readership and understanding about biotechnology as well as willingness to purchase an ornamental plant or grass if modified by biotechnology. Modified Likert scales, in which 0 was "not important" and 4 was "extremely important" to respondents, were used to assess perceived value of an ornamental shrub if each of 10 listed plant characteristics were altered by biotechnology.

Participants were asked to indicate their belief about whether it is acceptable to genetically modify an ornamental shrub by adding an extra gene either from the same shrub or from different classes of organisms and to identify their level of concern about GM ornamental plants compared with GM foods. An 11-point scale anchored by $-5=$ "extremely bad" and 5 = "extremely good", with 0 scored neutral, was used to reveal participant predictions about the relative affect on humans and the environment if GM plants were used in landscapes.

Further questions were posed about GM ornamental plants to identify belief about invasiveness, methods of marketing, requirements for labeling GM ornamental plants at point of sale, and the relative expected cost of GM vs. nonmodified ornamental plants. Questions were scored 1 = "strongly disagree" to $5=$ "strongly agree" and $1=$ "least" to 4 = "most". Master Gardener volunteers contributed personal demographic characteristics, including their personal investments in time and money to their home landscape or garden. Finally, because no prior research has explored consumer belief or expectation about GM ornamental plants, and these factors are expected to profoundly influence success of product commercialization, the survey concluded with a qualitative component allowing latitude for respondents to briefly describe their "biggest hope" and "concern" about biotechnology and GM ornamental plants.

After data were tabulated, missing variables and answers of respondents who indicated the "don't know" response option were excluded from analyses yielding slight differences in sample sizes among individual questions. Frequencies of valid responses were recorded and data were further assessed using chi-squared comparisons, Student $t$ - and Pearson's correlation coefficient tests. A two-factor multivariate analysis of variance tested the influence of Master Gardener's willingness "to take chances" and their highest completed level of education to describe the measure of concern expressed about relative risk or benefit posed by GM organisms and GM ornamental plants to humans and the environment (SPSS, 2003).

\section{Results}

By Sept. 2004, respondents returned 602 completed surveys yielding a response rate of $\approx 33 \%$ from our target audience. Respondent demographics describe a well-educated female, 45 years old or older with moderate household income and most likely to have completed Master Gardener certification (Table 1). Participants reported spending an average of $\$ 650( \pm \$ 38)$ a year and $37.6( \pm 1.6)$ hours a month to work in home landscapes and gardens with respondents indicating they performed $87 \%( \pm 0.9 \%)$ of the work themselves. Of 18 tested variables, none differed on the basis of Master Gardener status, whether certified or intern $(t=1.5$ to -0.12 ; df $=589-423 ; P=0.13-0.90)$.

Using Cronbach's reliability analysis, we determined that individual responses to the first three questions (Q1-3) of the survey yielded too few parameters to generate a valid "risk aversion" value (Table 2). Reliability measures (coefficient alpha $=0.47$ ) did not exceed the acceptable lower threshold of 0.70 (Nunnally, 1978). Thus, Master Gardener perceptions about biotechnology and GM ornamental plants are discussed independently in relation to either preference for "taking chances" or willingness "to try new things" or "new ways of doing things".

Although average Master Gardener expectations about GM ornamental plant use in the landscape had a slight positive skew to beneficial results for human health and the environment, most respondents indicated a neutral influence [Q12]. If modified genetically, ornamental plants were believed to possess "about the same" or "less" concern for "invasiveness" than nonmodified ornamental plants [Q14] (Table 2). Respondents also expressed differing levels of relative acceptance for gene insertions originating from nonsimilar source organisms [Q10] and placed different values on the types of genetic alterations to ornamental plant characters. For example, alterations of "pest-" and "disease-resistance" characteristics received the highest average importance values, whereas "seed or fruit production" and "pollen production" had lowest average importance values [Q9] (Table 2).

Responses to the question exploring beliefs about risk or benefit to human health from "biotechnology and genetically modified organisms" [Q6] may have been confounded. Because biotechnology is a means of obtaining a GM organism, these concepts should have been considered independently. However, a different series of questions described participant expectation about the potential affects of using GM ornamental plants in the landscape [Q12]. Survey participants anticipated slightly positive outcomes
Table 1. Descriptive characteristics of Master Gardener respondents from Tennessee who returned the completed four-page questionnaire.

\begin{tabular}{|c|c|}
\hline Characteristic & $\begin{array}{l}\text { Percentage of } \\
\text { respondents }\end{array}$ \\
\hline Number of respondents & 608 \\
\hline \multicolumn{2}{|l|}{ Gender } \\
\hline Male & 22 \\
\hline Female & 72 \\
\hline Did not respond & 6 \\
\hline \multicolumn{2}{|l|}{ Master Gardener status } \\
\hline Certified & 58 \\
\hline Intern & 40 \\
\hline Did not respond & 2 \\
\hline \multicolumn{2}{|l|}{ Age group (range) } \\
\hline $15-24$ & $<1$ \\
\hline $25-34$ & 3 \\
\hline $35-44$ & 10 \\
\hline $45-54$ & 29 \\
\hline $55-64$ & 36 \\
\hline Over 65 & 22 \\
\hline Did not respond & $<1$ \\
\hline \multirow{2}{*}{\multicolumn{2}{|c|}{$\begin{array}{l}\text { Highest level of } \\
\text { education completed }\end{array}$}} \\
\hline & \\
\hline High school & 11 \\
\hline Some college & 25 \\
\hline Associates degree & 8 \\
\hline Bachelor's degree & 23 \\
\hline Some graduate school & 9 \\
\hline Master's degree & 21 \\
\hline Doctorate & 3 \\
\hline Did not respond & $<1$ \\
\hline \multicolumn{2}{|l|}{$\begin{array}{l}\text { Estimated gross household } \\
\text { income (range) }\end{array}$} \\
\hline Less than $\$ 29,999$ & 12 \\
\hline$\$ 30,000-69,999$ & 38 \\
\hline$\$ 70,000-99,999$ & 22 \\
\hline$\$ 100,000-129,999$ & 10 \\
\hline More than $\$ 130,000$ & 11 \\
\hline Did not respond & 7 \\
\hline
\end{tabular}

to both human health $(t=11.32$; df $=584$; $P<0.001)$ and the environment $(t=4.75 ; \mathrm{df}=$ 581; $P<0.001$ ) (Fig. 1). More, answers provided for these questions compared reliably with answers given for the confounded question about biotechnology and GM organisms (coefficient alpha $=0.98$ ). This result suggests that Master Gardeners not only equate the terms "biotechnology" and "genetically modified organisms," but also believe them to generate slightly beneficial effects for human health and the environment (Table 2). Also, preference for "taking chances" and highest level of completed education did not influence Master Gardener perceptions about risks or benefits that GM organisms and GM ornamental plants pose to either human health or the environment $(F=0.21$ to $0.99 ; \mathrm{df}=23,515 ; P=$ $0.47-0.93)$.

By contrast, gender differences among respondents did yield differences in perception about acceptance of GM organisms in general and GM ornamental plants in particular (Table 3). Relative concern for GM ornamentals, compared with GM foods, also varied depending on gender of respondent $\left(\chi^{2}{ }_{[3]}=20.93 ; P<0.001\right)$. A crude odds ratio of gender summed within each of the two response groups reveals females were 4.2 times more likely than males to indicate "about the same" or "more concerns" for GM ornamentals than GM foods (Fig. 2). 
Table 2. Questionnaire content and summary statistics of variable means used in analyses of Master Gardener responses to questions revealing perceptions about genetically modified (GM) organisms and GM ornamental plants.

\begin{tabular}{lccc}
\hline Variable & $\begin{array}{c}\text { Mean } \\
(\text { SEM) }\end{array}$ & Minimum & Maximum \\
\hline [Q1] When possible, I prefer to avoid taking chances. & $0.09(0.05)$ & -2 & $2^{\mathrm{z}}$ \\
[Q2] I like to experiment with new ways of doing things. & $0.24(0.05)$ & -2 & 2 \\
[Q3] I am cautious in trying new or different things. & $0.62(0.04)$ & -2 & 2 \\
[Q4] How much have you read or heard about biotechnology? & $2.29(0.04)$ & 0 & $4^{\mathrm{y}}$ \\
[Q5] How well do you feel that you understand biotechnology? & $3.74(0.09)$ & 1 & $10^{\mathrm{x}}$ \\
[Q6] To what extent do you feel that biotechnology and & $0.44(0.11)$ & 0 & 4
\end{tabular}

genetically modified organisms are risky or beneficial to human health?

[Q7] Do you know of any bioengineered ornamental plants that you can already buy at a nursery or garden center?

[Q8] All things being equal (plant costs, appearance, size, etc.), would you be likely to buy ornamental plants or grasses if they had been modified by biotechnology?

[Q9] From a consumer's perspective, what value do you place on the use of biotechnology to alter the following plant characteristics in a flowering ornamental shrub? Number of flowers

Size of flowers

Length of flowering period

Flower color

Flower fragrance

Plant longevity

Pest resistance

Disease resistance

Seed or fruit production

Pollen production

[Q10] Do you believe it is acceptable to genetically modify

an ornamental shrub by adding an extra gene?

From a virus

From the same shrub

From a fungus

From a different plant

From an animal

From a bacteria

[Q11] Compared with genetically modified foods, what level of concern would you say that genetically modified ornamental plants present?

[Q12] What results do you predict if genetically modified ornamental plants are used in landscapes?

Affect on humans

Affect on the environment

[Q13] What long-term environmental impact do you predict from scientists making genetic modifications to the following types of plants?

Trees

Shrubs

Perennials

Annuals

Grass/turf

Vines/groundcovers

[Q14] Compared with nonmodified ornamental plants, what level of invasiveness would you expect a genetically modified ornamental plant to have?

[Q15] A humorous approach to naming a genetically modified ornamental plant can help reduce consumer concerns about biotechnology.

How do you feel about this statement?

[Q16] A nursery or garden center should be required to indicate the plants that are genetically modified on the plant label.

How do you feel about this statement?

[Q17] Compared with nonmodified ornamental plants,

how do you expect a genetically modified ornamental plant to cost?

"Scalar range: $-2=$ "strongly disagree" to $2=$ "strongly agree".

"Scalar range: $0=$ "least" to $4=$ "most".

"Scalar range: $1=$ "not at all" to $10=$ "very well".

"Scalar range: $0=$ "no" and $1=$ "yes".

"Scalar range: $-5=$ "extremely bad" to $5=$ "extremely good".

"Scalar range: $1=$ "strongly disagree" to $5=$ "strongly agree".

"Scalar range: $0=$ "free" and $1=$ "less" to $3=$ "more".
Gender of respondents did not predict whether gene modifications to an ornamental shrub would be acceptable if the inserted gene originated from the same shrub $\left(\chi^{2}{ }_{[1]}=\right.$ $0.05 ; P=0.83)$ or a different plant $\left(\chi_{[1]}^{2}=\right.$ 3.29; $P=0.07)$. However, males were more likely than females to accept modifications achieved by inserting a gene from a fungus $\left(\chi_{[1]}^{2}=6.9 ; P=0.009\right)$, bacteria $\left(\chi_{[1]}^{2}=\right.$ 12.44; $P<0.001)$, virus $\left(\chi_{[1]}^{2}=16.46 ; P<\right.$ $0.001)$, or animal $\left(\chi_{[1]}^{2}=4.40 ; P=0.036\right)$ (Fig. 3).

Types of plants were also perceived differently by male and female participants when anticipating environmental impact from genetic modifications $\left(\chi^{2}{ }_{[3]}=20.93\right.$; $P<0.001)$. On average, all perceived slight environmental benefits, but males predicted greater benefit from GM perennials, whereas females indicated GM grass/turf. Male and female respondents predicted least long-term benefit from GM trees and vines, respectively (Table 2). Male and female respondents also had different beliefs about the invasive potential of $\mathrm{GM}$ ornamental plants $\left(\chi_{[3]}^{2}=\right.$ 18.05; $P<0.001)$, with females more likely to predict GM ornamental plant escape.

Master Gardener volunteers were optimistic and indicated willingness to purchase GM ornamental plants should they be made available [Q8] (Fig. 4), but purchase behaviors were not predictable on the basis of gender $\left(\chi_{[4]}^{2}=6.90 ; P=0.14\right)$. More critically, survey respondents who rejected any of the sources of genes for insertion $\left(\chi_{[2]}^{2}=\right.$ $22.65 ; P<0.001)$, or indicated preferential avoidance of taking chances $\left(\chi^{2}{ }_{[6]}=20.68\right.$; $P=0.002)$, expressed greater unwillingness to buy a GM ornamental plant. Similarly, Master Gardener volunteers who perceived concerns about GM ornamental plants relative to GM foods [Q11] were less willing to purchase a GM ornamental plant $\left(r_{[597]}=\right.$ -0.286; $P<0.001)$. A humorous marketing strategy was also not likely to be effective [Q15], regardless of stated perception of risk from GM organisms, biotechnology, or GM ornamental plants $\left(r_{[414-425]}=0.095\right.$ to 0.036 ; $P<0.15-0.46)$. Indeed, Master Gardeners agreed with a stated requirement for labeling [Q16] to identify GM ornamental plants at point-of-sale when risks were perceived to human health associated with GM organisms $\left(r_{[535]}=-0.330 ; P<0.001\right)$ and GM ornamental plants $\left(r_{[547]}=-0.216 ; P<0.001\right)$, and from GM ornamental plants to the environment $\left(r_{[543]}=-0.248 ; P<0.001\right)$.

Patterns of hope and concern expressed by survey participants about GM ornamental plants were reduced into thematic areas (Day, 1994). Perceptions of GM ornamental plant release were expressed from three consequential positions: 1) environmental, 2) moral or ethical, and 3) economic. Principal environmental issues included hope that GM ornamental plants would not escape cultivated settings or become invasive in the landscape. These subjects were frequently paired with statements about the element of surprise or allusion to monstrosities and "unknowable" long-term outcomes, 


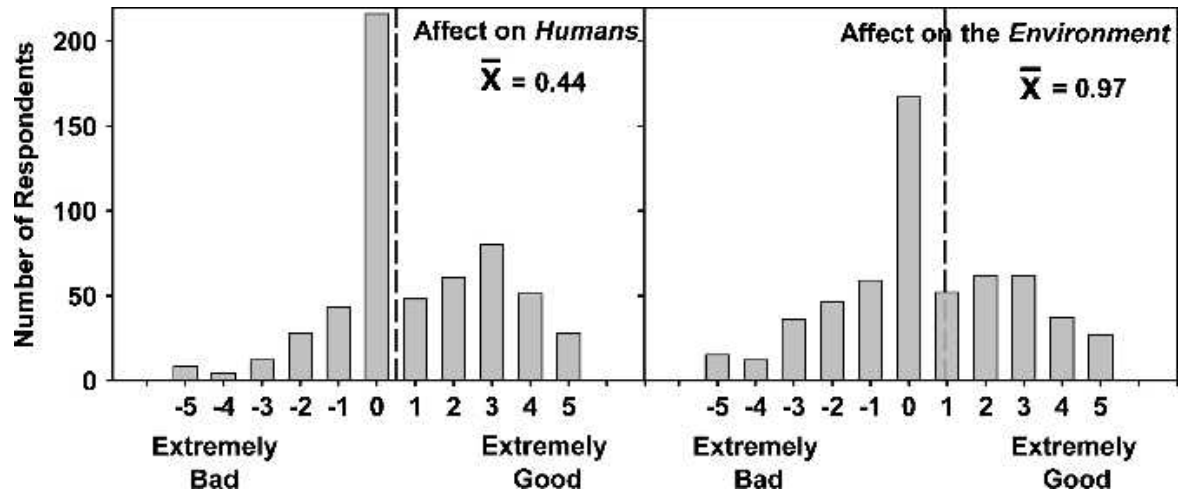

Fig. 1. Surveyed distribution of Master Gardener responses when asked: "What results do you predict if genetically modified ornamental plants are used in landscapes?" The largest number of respondents indicated neutral outcomes from GM ornamental plant release. Average expectations, indicated by dashed line, differed slightly in perceived affect on humans $(\mathrm{n}=585)$ vs. affect on the environment $(\mathrm{n}=$ 581).

concepts often described as "dread" fears (Slovic et al., 1985). The environmental theme included statements of hope or concern about the influence of GM ornamental plants on pollinators. Potential "loss" of native plants or heirloom plant varieties and statements about "transfer" of genetically modified characters to fruit and vegetable crops were frequently expressed. Respondents also emphasized "(Mother) Nature" and God, stating desire that "the balance of Nature" not be upset by GM ornamental plant release. Others voiced rejection of GM technology as contrary to Divine Will. Finally, Master Gardeners anticipate economic challenges that high plant development costs will result in cost-prohibitive products at retail.

Finally, Master Gardener comments also evinced belief about roles that scientists and regulators perform toward developing and introducing GM commodities. Participants urged caution and "thorough" testing using "good" science under appropriate supervision. Many respondents questioned "who", "how", and "what" regulatory oversight moderates university, industry, and govern-

mental GM plant research. Several made allegorical references to "renegade" scientists, "uncontrolled" experimentation, or advances made solely to achieve economic gain.

\section{Discussion}

Demographically, a typical Master Gardener program volunteer would most likely be a married, white female, 55 years old or older, who has attended some semesters of college or completed a college degree and living in a suburban neighborhood with an annual gross income exceeding $\$ 50,000$ (Amundsen et al., 1997; Rohs et al., 2002; Schrock et al., 1999). Master Gardener program participants are expected to have greater-than-average interest and knowledge about gardening and plant materials than the general public, particularly once training for certification is complete.

We acknowledge Master Gardener volunteers are not representative of U.S. public consumers of foods or staple goods. Yet compared with public consumers of general goods, our respondent demographics typify
Table 3. Survey response means among genders illustrate differences in Master Gardener belief and perception about benefit or risk associated with genetically modified (GM) ornamental plants.

\begin{tabular}{|c|c|c|c|c|c|}
\hline Variable & Female & Male & $t$-value & $\mathrm{df}$ & $P$ Value \\
\hline $\begin{array}{l}\text { Knowledge of } \\
\text { biotechnology }\end{array}$ & 3.43 & 4.72 & 6.178 & 564 & $<0.001$ \\
\hline $\begin{array}{l}\text { Risk/benefit of GM } \\
\text { organisms to human health }\end{array}$ & 0.25 & 1.18 & 3.575 & 530 & $<0.001$ \\
\hline $\begin{array}{l}\text { GM ornamental plant risk/ } \\
\text { benefit to human health }\end{array}$ & 0.86 & 1.32 & 2.205 & 543 & 0.028 \\
\hline $\begin{array}{l}\text { GM ornamental plant risk/ } \\
\text { benefit to environment }\end{array}$ & 0.33 & 0.73 & 1.723 & 540 & 0.09 \\
\hline \multicolumn{6}{|l|}{$\begin{array}{l}\text { Environmental impact of } \\
\text { genetic modifications to }\end{array}$} \\
\hline Trees & $0.86(5)^{z}$ & $1.49(5)$ & 2.371 & 532 & 0.018 \\
\hline Shrubs & $0.90(4)$ & $1.71(3)$ & 3.196 & 528 & 0.001 \\
\hline Perennials & $1.01(3)$ & $1.75(1)$ & 3.057 & 530 & 0.002 \\
\hline Annuals & $1.05(2)$ & $1.71(3)$ & 2.594 & 528 & 0.01 \\
\hline Grass/turf & $1.11(1)$ & $1.74(2)$ & 2.345 & 529 & 0.019 \\
\hline Vines/groundcovers & $0.77(6)$ & $1.56(4)$ & 2.988 & 529 & 0.003 \\
\hline $\begin{array}{l}\text { Use of humor to reduce } \\
\text { consumer concerns }\end{array}$ & 2.47 & 2.66 & 1.327 & 408 & 0.18 \\
\hline $\begin{array}{l}\text { Requirement for labeled } \\
\text { GM ornamental plants }\end{array}$ & 4.38 & 4.14 & -2.989 & 530 & 0.003 \\
\hline
\end{tabular}

${ }^{\mathrm{z}}$ Values in parentheses represent the ranked acceptance within gender. characteristics of U.S. consumers who buy Green Industry goods and ornamental plants (ANLA, 2000; Klingeman et al., 2004; National Gardening Association, 2005). For example, ornamental plant consumers typically have higher household incomes and broader educational backgrounds than nongardeners (ANLA, 2000; National Gardening Association, 2005; Safley et al., 2000).

In the United States, gardeners and doit-yourself home landscapers are also an increasingly well-educated consumer segment (Klingeman et al., 2004; National Gardening Association, 2005). When questioned in conjunction with active purchases of ornamental plants, consumers report a self-confident ability to determine health and anticipated performance of annual and bedding plants without assistance from retail sales staff. However, they do admit less certainty about what constitutes healthy plant appearance for perennials, shrubs, and trees as well as how such plants would be expected to perform in their landscapes (Day, 1994).

To answer these questions, green goods consumers rely on independent garden centers, magazines, and friends, including Master Gardener volunteers, as major outlets of information about gardening and landscape plant materials (Day, 1994; Safley and Wohlgenant, 1995). We expect that several conclusions from our research can be integrated with this information stream to proactively guide academic education and outreach efforts. In turn, success will likely increase U.S. public acceptance of GM ornamentals.

Importantly, survey respondents in Tennessee indicated that the same ethical issues raised by debate about GM foods would persist with attempts to introduce GM ornamental plants. In our study, this was evident most notably among women. Similarly, women have voiced greater opposition to GM foods than men, identifying environmental and food safety concerns (Florkowski et al., 1999; Hoban et al., 1992; Mellman Group and Public Opinion Strategies, 2005). This point is important to the Green Industry because women represent $\approx 70 \%$ of consumers that purchase ornamental plants (ANLA, 2000). Thus, marketing for GM ornamental plants that emphasizes benefits of the product rather than the process used to achieve those benefits is expected to increase public acceptance (Boulter, 1997; Hallman, 1996).

Many in our study also expressed unknowable risks and "dread fears," related to modifications of GM ornamental plants, consistent with civic concern about other GM products (Boulter, 1997; Gaskell et al., 2004; Slovic et al., 1985). Belief about risks from agrobiotechnology has influenced public attitudes more than benefits perceived of GM products (Gaskell et al., 2004; Moon and Balasubramanian, 2004; Rousu et al., 2005). The lack of perceived benefit from GM products has arguably been the biggest roadblock to public acceptance of GM technology independent of perceived level of risk (Gaskell et al., 2004). In this regard, ornamental plants should afford 


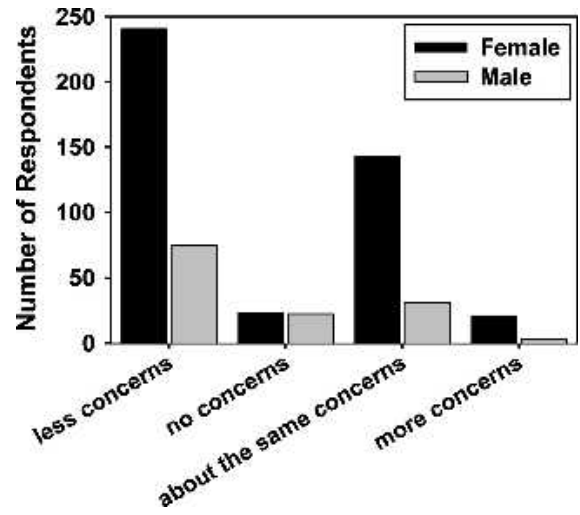

Fig. 2. Male and female Master Gardeners perceived different levels of concern about genetically modified (GM) ornamental plants when asked to compare GM foods with GM ornamental plants.

unique opportunities to introduce a GM product with desirable and readily apparent benefit to U.S. gardeners and landscapers. Although GM modification to pollen and seed averaged lower values for perceived importance, such alterations may reduce plant invasiveness, which many respondents voiced as a critical concern.

Academic proponents of biotechnology should present attributes of GM products realistically, emphasizing distinct product benefits while clearly describing limitations of the GM commodity (Gaskell et al., 2004; Tiedje et al., 1989). For example, GM plant transformations that result in a true blue rose will not necessarily confer resistance to black spot or powdery mildew in the landscape. Also, a GM ornamental plant made resistant to a specific plant pathogen will not be equally resistant to insect-feeding activity. We would still expect either of these GM introductions to succeed by satisfying a specific consumer interest or need in an ornamental plant. However, to be socially relevant, discussion of GM plant attributes should not neglect economic, environmental, and ethical viewpoints (Boulter, 1997; Cantley et al., 1999; Moon and Balasubramanian, 2004; Uzogara, 2000). By ignoring consumer perception and concern, we risk losing civic trust.

The public already questions motives for commercializing GM products, particularly by industrial entrepreneurs (Gaskell et al., 2004). In particular, skepticism has emphasized agribusiness claims of economic trickle-down to growers using GM crops in developing nations and uncertainty about patenting living organisms (Boulter, 1997; Gaskell et al., 2004). Once public trust is lost, it is not regained readily, if ever (Cantley et al., 1999). As GM products are introduced, the public expects government and industry leaders to demonstrate that regulatory procedures are sufficient and able to keep them safe (Boulter, 1997; Gaskell et al., 2004). Currently, however, U.S. consumer knowledge about GM organisms remains limited (Mellman Group and Public Opinion Strategies,

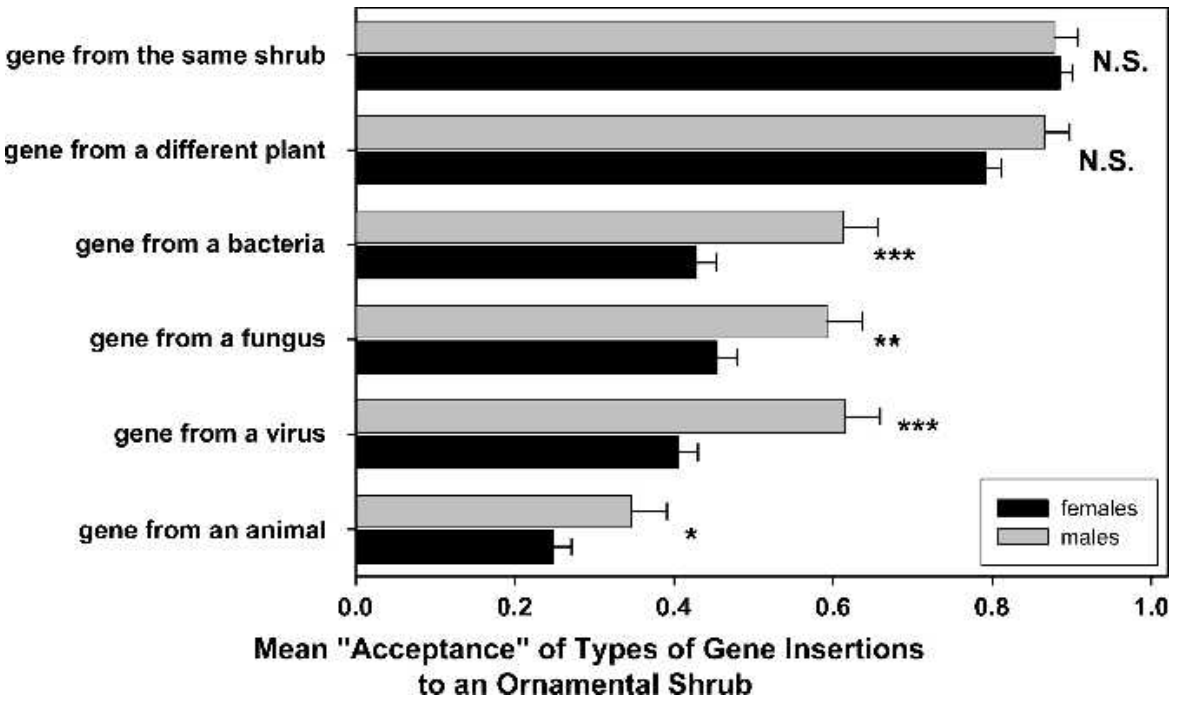

Fig. 3. Mean belief among survey participants that it is acceptable to genetically modify an ornamental shrub by adding a extra gene from different types of organisms (following Hoban, 1993). Where indicated within organism type, males and females had different opinions about the acceptability of inserting an additional gene from that organism into the hypothetical ornamental shrub by chi-squared test at $\alpha=0.05$. Single, double, and triple asterisks $\left(^{*}\right)$ denote the asymptotic two-tailed test was significantly different at $P<0.05,0.01$, or 0.001 , respectively.

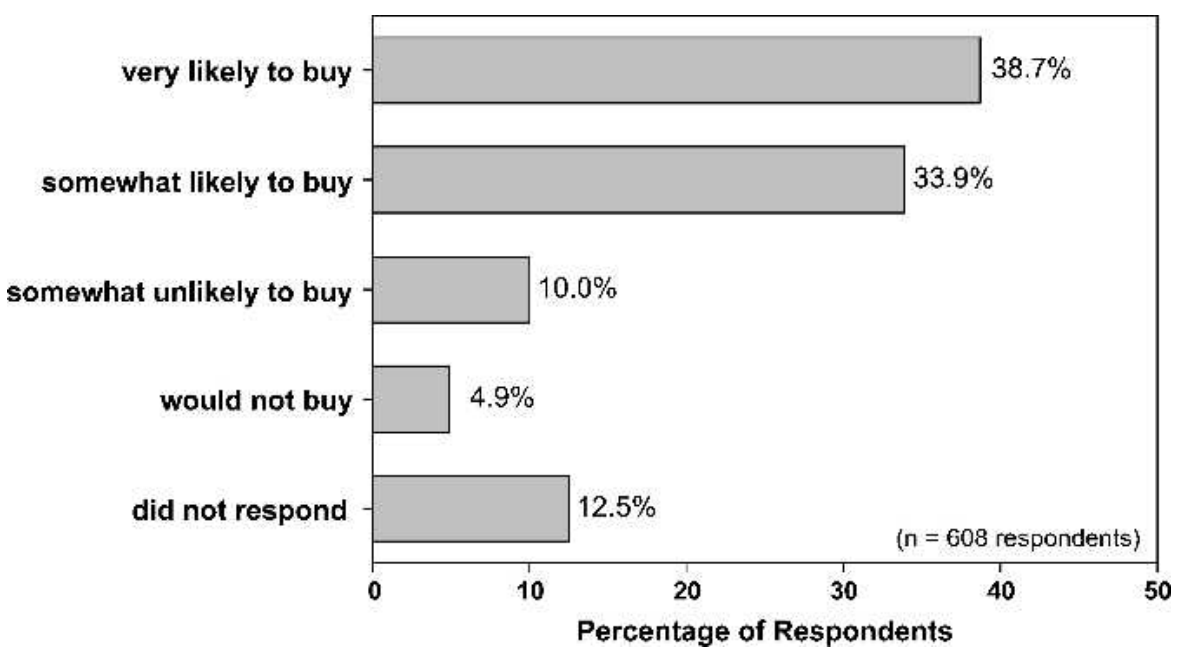

Fig. 4. Respondents' self-reported "willingness-to-purchase" ornamental plants or grasses modified by biotechnology under the stated assumption that "plant cost, appearance, size, etc." are equivalent to an identical nonmodified ornamental plant.

2005). Civic trust in the ability of scientists and governmental regulators to manage risk associated with GM organisms persists in tenuous balance, even in the United States (Argust, 2001; Beckwith et al., 2003; Cantley et al., 1999).

A survey of 1228 N.C. residents revealed fewer than $20 \%$ were "very confident" and just over $60 \%$ were "somewhat confident" of the decision-making capability of the USDA, EPA, FDA, and state agencies (Hoban, 1993). The position taken by ASLA may invigorate awareness about GM ornamental plant research underway in the United States. Indeed, the intent of Green Industry producers to introduce GM ornamental plants into highly visible locations in home landscapes may effectively volatilize dialogue about pushing Nature "beyond its limits" and challenging Divine Intent by disrupting the delicate balance of Nature (Boulter, 1997;
Marris, 2001). Master Gardener volunteers in Tennessee also expressed these beliefs.

Scientists are held to high public standards for credibility and trust (Boulter, 1997; Hails and Kinderlerer, 2003; Hallman, 1996). Ironically, historical and contemporary fictional stereotypes of scientists are largely negative (Boulter, 1997). More, ethical, safety, and social issues have largely been absent from scientific description of biotechnologic accomplishments, including popular press outlets, in publications from 1987 to 1994 (Hagedorn and Allender-Hagedorn, 1997). Consequently, public interest groups have interpreted this absence as contempt by scientists for public expression of concern and dissent (Beckwith et al., 2003; Cantley et al., 1999; Hagedorn and Allender-Hagedorn, 1997).

In direct response, perhaps, vocal opponents have become twice as prevalent as 
advocates of biotechnology and GM organisms (Beckwith et al., 2003; US-FDA, 2000). As scientists and extension professionals, our outreach should acknowledge perceptions that U.S. consumers share between GM foods and GM ornamentals. Furthermore, we should work to allay civic concern by increasing awareness of regulatory oversight and protections already established that ensure safety and security from both academic and corporate field tests of GM plant products (Braun, 2002; Cantley et al., 1999; Hails and Kinderlerer, 2003; Uzogara, 2000). We should avoid challenging consumer trust in our ethical or moral consciousness by describing biotechnologic advances as "creating new species" to achieve a desired objective by tailoring plant metabolic processes with biotechnology (Uzogara, 2000). Regardless, if we do not understand, thus cannot disarm, public perception about genetic alterations in plants, then GM ornamental commodities will not succeed commercially.

Finally, we expect our survey results to also have commercial relevance. Green Industry marketing efforts will not gain advantages by attempting to advertise and promote GM ornamental plants with humor as a means of allaying fears. Estimates of mandatory labeling efforts for GM foods are projected to place impractical burdens on U.S. food processing. In turn, this has been translated into cost increases projected to trigger consumer backlash, particularly if no appreciable benefits result (Lapan and Moschini, 2004; Moon and Balasubramanian, 2004).

By contrast, pairing an adequate marketing message (Rousu et al., 2005) with a voluntary labeling system for GM ornamental plant introductions will offer proactive growers and retailers, the means, at negligible cost, to acknowledge consumer desire for labeling and to address civic concern about GM products by offering customers informed choice at point-of-sale.

\section{Literature Cited}

Amundsen, D., D. Drost, and W. Varga. 1997. Utah's Davis County Master Gardener program. Horttechnology 7:354-356.

American Nursery and Landscape Association [ANLA]. 2000. The 2000 Grapevine Survey. Colburn House Publ., Washington, D.C. 115 p.

Argust, M. 2001. Fact sheet: genetically modified organisms. ASLA Online. Available at: http:// www.asla.org/Members/publicaffairs/fact- sheets/genmodorg.html. Accessed 23 Jan. 2006.

Avise, J. 2004. The Hope, Hype, and Reality of Genetic Engineering. Oxford Univ. Press, N.Y.

Beckwith, J.A., T. Hadlock, and H. Suffron. 2003. Public perceptions of plant biotechnology-a focus group study. N. Genet. Soc. 22:93-109.

Boulter, D. 1997. Scientific and public perception of plant genetic manipulation-a critical review. Crit. Rev. Plant Sci. 16:231-251.

Braun, R. 2002. People's concerns about biotechnology: some problems and some solutions. J. Biotechnol. 98:3-8.

Cantley, M., T. Hoban, and A. Sasson. 1999. Regulations and consumer attitudes toward biotechnology. Nat. Biotechnol. 17:37-40.

CSIRO Plant Industry. 2005. World's first blue rose. Available at: http://www.csiro.au/files/ files/p29z.pdf. Accessed 1 Feb. 2006.

Day, E. 1994. An exploratory study of garden center selection for landscape plants. J. Environ. Hort. 12:142-146.

Florkowski, W.J., C. Halbrendt, C.L. Huang, and L. Sterling. 1999. Socioeconomic determinants of attitudes toward bioengineered products. Rev. Agr. Econ. 16:125-132.

Gaskell, G., N. Allum, W. Wagner, N. Kronberger, H. Torgersen, J. Hampel, and J. Bardes. 2004. GM foods and the misperception of risk perception. Risk Anal. 24:185-194.

Gaskell, G., M.W. Bauer, J. Durant, and N.C. Allum. 1999. Worlds apart? The perception of genetically modified foods in Europe and the U.S. Science 285:384-387.

Hagedorn, C. and S. Allender-Hagedorn. 1997. Issues in agricultural and environmental biotechnology: identifying and comparing biotechnology issues from public opinion surveys, the popular press and technical/regulatory sources. Public Understand.Sci. 6:233-245.

Hails, R. and J. Kinderlerer. 2003. The GM public debate: context and communication strategies. Nat. Rev. Genet. 4:819-825.

Hallman, W.K. 1996. Public perceptions of biotechnology: another look. Biotechnology (N.Y.) 14:35-38.

Hoban, T.J. 1993. Biotechnology: consumer attitudes. Agr. Outlook 20:20-23.

Hoban, T.J., E. Woodrum, and R. Czaja. 1992. Public opposition to genetic engineering. Rural Sociol. 57:476-493.

Klingeman, W.E., D.B. Eastwood, J.R. Brooker, C.R. Hall, B.K. Behe, and P.R. Knight. 2004. Consumer survey identifies plant management awareness and added value of powdery mildew-resistant dogwoods. Horttechnology 14:275-282.

Lapan, H.E. and G. Moschini. 2004. Innovation and trade with endogenous market failure: the case of genetically modified products. Am. J. Agric. Econ. 86:634-648.

Marris, C. 2001. Public views on GMOs: deconstructing the myths. EMBO Rep. 21:545-548.

Mellman Group and Public Opinion Strategies. 2005. Public sentiment about genetically modified foods: report to the Pew Initiative on food and biotechnology. Available at: http:// pewagbiotech.org/research/2005update/ 2005summary.pdf. Accessed 2 Feb. 2006.

Moon, W. and S.K. Balasubramanian. 2004. Public attitudes toward agrobiotechnology: the mediating role of risk perceptions on the impact of trust, awareness, and outrage. Rev. Agr. Econ. 26:186-208.

National Gardening Association. 2005. National Gardening Survey 2004. National Gardening Association, South Burlington, Vt.

Nunnally, J.C. 1978. Psychometric. Theory, 2nd ed. McGraw-Hill, N.Y.

Rohs, F.R., J.H. Stribling, and R.R. Westerfield. 2002. What personally attracts volunteers to the Master Gardener program? J. Extension 40. Available at: http://www.joe.org/joe/2002 august/rb5.shtml.. Accessed 23 Jan. 2006.

Rousu, M.C., D.C. Monchuk, J.F. Shogren, and K.M. Kosa. 2005. Consumer willingness to pay for 'second-generation' genetically engineered products and the role of marketing information. J. Agr. Appl. Econ. 37:647-657.

Ruppert, K.C., J. Bradshaw, and A.Z. Stewart 1997. The Florida Master Gardener program: history, use, and trends. Horttechnology 7:348353.

Safley, C.D. and M.K. Wohlgenant. 1995. Factors influencing consumer's selection of garden centers. J. Agribusiness 12:33-50.

Safley, C.D., M.K. Wohlgenant, and C. DiRienzo. 2000. Economic and socioeconomic factors affecting consumer purchases of fall nursery products: Fall 1997 consumer survey. NCCES/ NCAN/NCDACS Agric. Res. Econ. Rep. 19, 28.

Schrock, D.S., M. Meyer, P. Ascher, and M. Snyder. 1999. Missouri Master Gardener Demographics. J. Extension 37. Available at: http://www.joe.org/joe/1999october/rb4.html. Accessed 23 Jan. 2006.

Slovic, P., B. Fischoff, and S. Lichtenstein. 1985. Characterizing perceived risk. In: R.W. Kates, C. Hohenemser, and J.Z. Kasperson (eds.), Perilous Progress: Managing the Hazards of Technology. Westview Press, Boulder, Colo. p. 91-125.

SPSS. 2003. SPSS Version 12.0 for Windows, SPSS Inc., Chicago, Ill.

Tiedje, J.M., R.K. Colwell, Y.L. Grossman, R.E. Hodson, R.E. Lenski, R.N. Mack, and P.J. Regal. 1989. The planned introduction of genetically engineered organisms: ecological considerations and recommendations. Ecology 70:297-315

US-FDA. 2000. Report on consumer focus groups on biotechnology. Center for Food Safety and Applied Nutritiont. A.S. Levy and B.M. Derby (eds.). Available at: http://www.cfsan.fda.gov/ $\sim$ comm/biorpt.html. Accessed 5 Aug. 2004.

Uzogara, S.G. 2000. The impact of genetic modification of human foods in the $21 \mathrm{st}$ century: a review. Biotechnol. Adv. 18:179206. 